\section{Party officials accused of screening Interior advisers}

\section{Washington}

TEN members of a scientific advisory panel of the Department of the Interior were not reappointed last year after they failed to receive "clearance" from the Republican National Committee (RNC). Four other scientists who were cleared by the political group were kept on.

The incident was revealed in a memorandum obtained last seek by Senator Dale Bumpers (Democrat, Arkansas) under the Freedom of Information Act. The memorandum, headed "Appointment Clearance Request - Advisory Committee", was sent on 29 January 1982 from the Office of the Secretary of the Interior to RNC. It lists 14 names with blanks after each; the handwritten word "yes" or "no" has been filled in in all but one of the blanks. Only those receiving a "yes" were reappointed (or, in one case, appointed anew) to the advisory committee (the Scientific Committee of the Outer Continental Shelf Advisory Board).

Dr Robert Beardsley of the Woods Hole Oceanographic Institution, a former member of the committee who received a "no" rating, said the group advised the Bureau of Land Management on the scientific merit of research supported by the bureau. "It was not a policy forum", he said. "We never even discussed issues like should there be accelerated lease sales of federal land", one of Secretary James Watt's most controversial policies.

Beardsley said that a meeting of the committee scheduled for early 1982 - the first since the Reagan Administration came in - was cancelled "at the last moment". A couple of months later, he received a form letter saying that his name had been taken off the mailing list.

A spokesman for RNC, Bill Greener, confirmed that RNC had carried out clearance checks on the scientists, and on candidates for other advisory committees and government posts. "What we have done is widespread and extensive" , he said. "The only exceptions are Defense, State and Justice."

Greener said "All we do is ascertain that the people are registered (to vote) and are Republicans. We are not passing any judgment whatsoever. A 'yes' means that an individual is registered and a Republican."

Greener said that Carol Williams, the RNC official to whom the memorandum was sent, was a "junior staffer" in the office that handles "White House liaison", Williams, who is now at the Department of Education, refused to comment. The Interior Department official who wrote the memorandum, Derrell Thompson, refused to speak to a reporter who reached him at his Denver, Colorado, office.

The incident is the latest - and most serious - episode in the continuing story of political manipulation of scientific advisory panels by the Reagan Administration. Congressional investigators looking into allegations of misconduct at the Environmental Protection Agency recently found lists that rated the political leanings of the agency's scientific advisers and senior civil servants. Last year, Food and Drug Administration officials complained that they were being pressed to accept politically inspired choices for posts on independent advisory panels. Also last year, the Department of Agriculture beat a hasty retreat after it was revealed that scientists selected to serve on peer-review panels were being subjected to political checks.

The Interior Department case, however, reveals for the first time the extent of the

\section{Genetic manipulation}

THE British Government is proposing that its Genetic Manipulation Advisory Committee (GMAG), responsible for licensing experiments in genetic manipulation, should have a less active role but that investigators should continue to disclose experiments they carry out. This proposal is one of four for the future of GMAG contained in a consultative document issued on 5 April and circulated for

The document says that the need to review GMAG's function arises because of "growing indications that early fears about the risks involved in genetic manipulation were exaggerated" (which will seem to many an injudicious phrase), because such concerns as remain about safety centre on large-scale production and because of the reorganization of arrangements for regulating work with dangerous pathogens.

The government is obviously also bothered by the anomalous constitution of GMAG, which by an historical accident has been sponsored since 1976 by the Department of Education and Science under the nose of the then infant Health and Safety Executive and of its supervisory commission, which have direct responsibility for occupational health. The consultative document says that the government departments needing advice no longer include education and science but those responsible for agriculture, environment and industry.

The proposed reorganization, said to have been discussed by GMAG itself, is the favourite among four alternatives comment (by 31 May).

role played by $\mathrm{RNC}$, and raises the possiblility that many other scientific advisory appointments were similarly scrutinized. "If that group is subjected to political tests, then anybody could be", said James Bruce, a Democratic counsel on the Senate Energy and Natural Resources Committee.

The case also raises the possibility that the law was violated. The charter of the Interior Department committee states that its members are to be selected for their "scientific competence, reputation within their particular fields of expertise, and ability to be representative of important elements of the OCS (Outer Continental Shelf) studies program". The law governing all federal advisory committees requires measures to assure that they "will not be inappropriately influenced by the appointing authority or by an special interest".

But the law does not provide for any criminal penalties, so any question of violation may be somewhat academic. A more critical question, Bruce said, is "What is the long-term impact of this on the willingness of scientists to serve on these panels?"'

Stephen Budiansky

\title{
Watchdog to bark less often
}

leaving GMAG alone, splitting it into two with responsibility for advising government departments and the health and safety establishments separately, turning it into a joint committee and, finally, transferring it into a dependant of the Health and Safety Executive as recommended. Presumably the first two options are intended derisorily. Abolition is not considered.

Under the proposed reorganization, the committee would be renamed the Health and Safety Commission Advisory Committee on Genetic Manipulation. It would advise the commission and executive on general questions, and give advice to government departments when asked.

The legal requirement that experiments should be notified to the executive would continue, as would the present voluntary undertaking by manufacturers that commercial-scale production plans would be notified. Such data would, however, be adjudicated by officials; only exceptional proposals would go to the committee.

Many researchers will ruefully reflect that the upshot of the proposed reorganization will be that a field of research whose hypothetical hazards are now said to have been "exaggerated" is nevertheless to remain perpetually under regulation. Although for most research laboratories, an annual retrospective report is now sufficient, the principle may stick in some throats.

The government also proposes that the four lay members of the present GMAG should be dispensed with. 